\title{
Corporate Leverage, Bankruptcy, and Output Adjustment in Post-Crisis East Asia
}

\author{
Se-Jik Kim and Mark R. Stone*
}

\begin{abstract}
This paper posits that different levels of corporate leverage help explain the very wide range of output adjustment across East Asia in response to the 1997-98 crisis. A general equilibrium model is presented where leverage and output are linked by low investment and capital sales triggered by the threat of bankruptcy. In the model developed here, highly leveraged firms facing a cutoff of capital inflows, which are threatened by bankruptcy, respond first by eliminating investment and then by selling their capital goods - at a discount - to try to stay afloat. Lower investment and wasteful capital sales shrink the aggregate capital stock, trigger deflationary pressures, and contract overall output. In contrast, less leveraged firms, which are not threatened by bankruptcy, would not have to respond by lowering investment and raising costly capital sales. Therefore, a higher corporate leverage may induce a greater output contraction during the crisis. The available data are consistent with the assumptions and predictions of the model.
\end{abstract}

Keywords: Corporate leverage, Bankruptcy, Crisis,

Output adjustment

JEL Classification: G33, E22, E23

* School of Economics, Seoul National University, Seoul 151-746, Korea, (Tel) +82-2-880-4020, (E-mail) skim@snu.ac.kr; International Monetary Fund, (E-mail) mstone@imf.org, respectively. We are grateful to Eduardo Borensztein, Chris Browne, Lorenzo Giorgianni, and Jeanne Gobat for helpful comments, and Ned Rumpeltin for excellent research assistance. We gratefully acknowledge the financial support from the Advanced Strategy Program (ASP) of the Institute of Economic Research, Seoul National University.

[Seoul Journal of Economics 2007, Vol. 20, No. 4] 


\section{Introduction}

The cutoff of capital inflows that triggered the East Asian crisis in 1997 was followed by a remarkably wide range of output responses. For example, the real GDP of Indonesia contracted by 14 percent in 1998, whereas for Taiwan Province of China real GDP expanded by 5 percent. What explains this wide disparity? This paper posits that cross-country differences in corporate leverage help explain the wide range of post-crisis output adjustment. This explanation is motivated by the fact that the cutoff of capital inflows affected all countries in the region, whereas the output contractions were most severe for those countries with high levels of corporate debt. Further, investment and inventory contractions in these countries accounted for the bulk of their output declines in 1998, and significant sales of physical capital were made at large discounts.

To link corporate leverage to output adjustment, this paper presents a general equilibrium small open economy model with bankruptcy and wasteful capital sales. In the model, firms borrow short-term foreign bonds, which may or may not be rolled over. If the bonds are not rolled over, which is an adverse and exogenous liquidity shock, there is a pecking order of firms' responses. Firms meet their debt obligations first by canceling dividends and cutting back investment, then by undertaking distress sales of physical capital at a discount. Firms unable to meet their debt obligations go bankrupt and must liquidate their capital, but at an even larger discount.

This model allows for the assessment of the impact of a cutoff of external credit on the real economy for economies with different levels of leverage. In a low debt economy, a cutoff of capital inflows has little or no impact on the real economy because firms need not curtail investment or sell their capital to stay afloat. By contrast, a cutoff of capital inflows contracts the aggregate output of economies with heavily leveraged firms. In the medium-debt case, firms stay afloat by eliminating investment and selling their capital at the distress discount. These actions shrink the capital stock, and subsequently decrease output. In the high-debt case, which is intended to proxy the highly leveraged East Asia countries, some firms go bankrupt and must not only eliminate investment but also sell all of their capital. Lower investment and capital sales again 

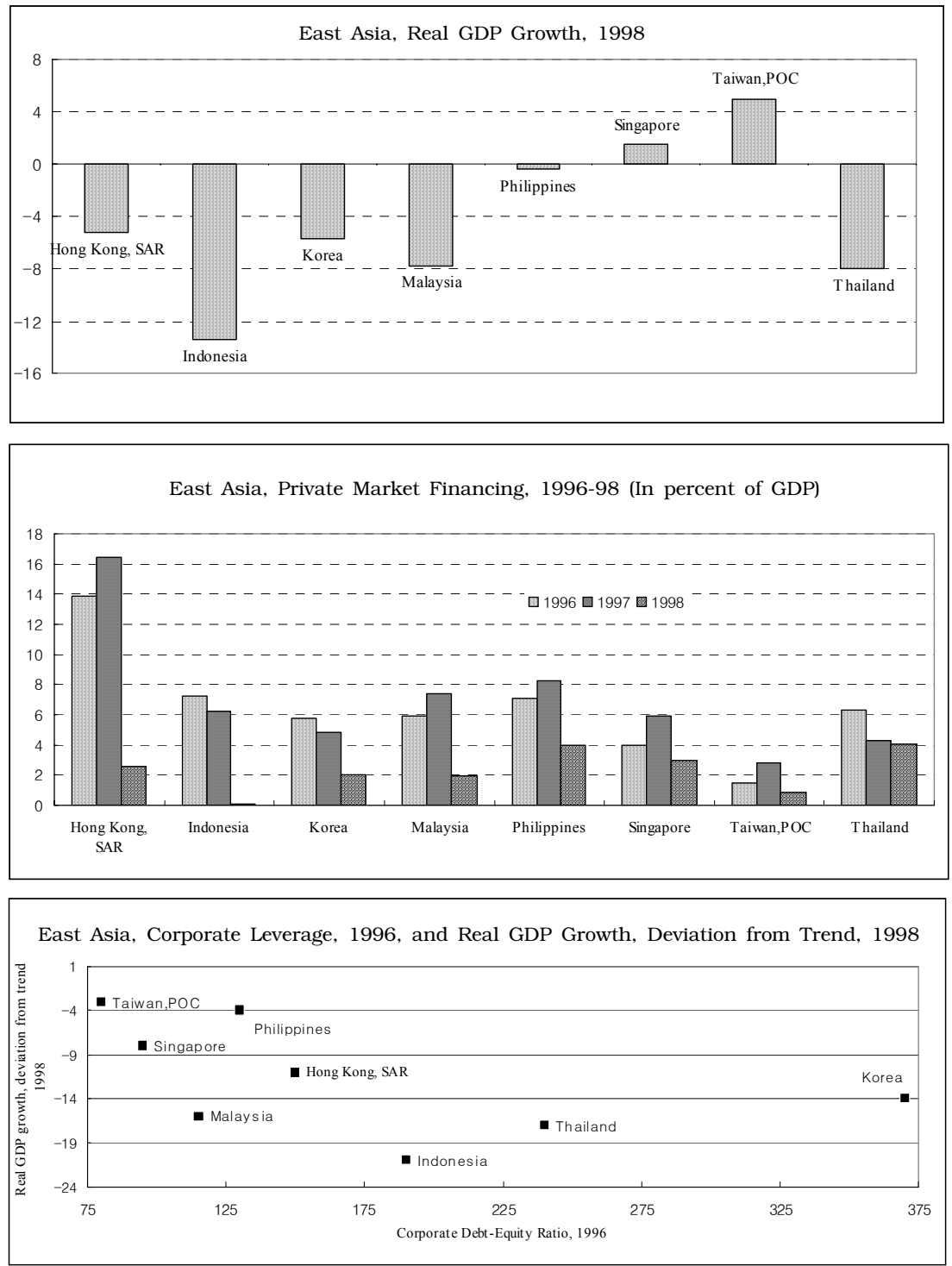

Sources: International Monetary Fund (1999) and Claessens et al. (1998).

\section{Figure 1}

EAST Asia: REAL Growth, CaPital Inflows AND Corporate LEVERAGE, 1996-98 
contract aggregate output, but by more than for a medium-debt economy, reflecting the tighter budget constraints and larger capital sales discount faced by liquidating firms. ${ }^{1}$

Furthermore, the model captures a future deflation channel. If firms borrow both one-and two-period bonds, the output contraction is amplified by extra future deflation. In this case, everybody knows that leveraged firms will have to sell capital next period as well as in the current period. These future capital sales will exert extra deflationary pressure today, further reducing investment and the capital stock, and amplifying the output contraction.

The available empirical evidence is then reviewed to gauge the validity of the assumptions and predictions of the model. The data indicate that the cutoff of external credit to East Asia was abrupt, large, and pervasive. The pre-crisis extent of corporate leverage in several East Asia countries was quite high by international standards, and a large number of corporations in these highly leveraged countries went bankrupt. Large contractions in investment, which is concentrated in the corporate sector, dragged down output during 1998 in the leveraged countries. Moreover, in Korea, and to a lesser extent in other countries, capital sales were made at substantial discounts. Thus, the available evidence seems to be broadly consistent with the assumptions and predictions of the model.

The literature on the East Asia crisis that deals with the origins of the crisis and aims to explain cross-country contagion is large. ${ }^{2}$ The most important of the overlapping and mutually reinforcing explanations of the origins of the crisis are: common external shocks (Masson 1998); cross-country trade and financial market linkages (Glick and Rose 1998); financial market contagion (Goldstein 1998; Calvo and Mendoza 1998); monetary policy that was too tight (e.g. Sachs and Radelet 1998) or too loose (Lane et al. 1999); tight fiscal

\footnotetext{
${ }^{1}$ Investment does not follow from an interior solution that strikes a balance between marginal gain and cost, as in the low-debt case; rather, investment is determined in a corner solution pulled down by the liquidity constraint.

${ }^{2}$ For analyses of the origins of the East Asia crisis, see Corsetti et al. (1998), Masson (1998), and Krugman (1999). For an overview of macroeconomic developments during the East Asia crisis see Coe and Kim (2002), World Bank (1998), Roubini et al. (1998), Lane et al. (1999), and Kochhar et al. (1998).
} 
policy (Sachs and Radelet 1998); domestic bank over lending (Corsetti et al. 1998; Krugman 1998; Dooley 1997); political risks (Roubini et al. 1998); and excessive corporate leverage via current account adjustment (Krugman 1999).

This paper, in contrast, is concerned with the aftermath of the crisis, and thus is complementary to much of the literature. ${ }^{3}$ Corporate leverage is taken as a starting condition, and is used to explain cross-country differences in output adjustment in response to a cutoff of capital inflows. This paper shares the view with Krugman (1999) in that corporate leverage explains the impact of a credit cutoff on output. This paper, however, emphasizes that leverage and output are linked by low investment and capital sales triggered by the threat of bankruptcy, while Krugman focuses on current account balance. 4

To concentrate on the impact of corporate leverage on output adjustment, we here do not address the market imperfections that led to the buildup of corporate debt in the first place. ${ }^{5}$ In addition, we abstract away banks (which in some countries channeled capital inflows to corporations) from the analysis, on the implicit assumption

\footnotetext{
${ }^{3}$ Output adjustments prompted by other crises of the 1990s have received considerable attention. The unexpected brevity of the recession in Mexico during 1994-95 was ascribed by Roubini et al. (1998) to strong growth in the U.S. and limited contagion. The prolonged output decline in the transition countries of eastern Europe during the early 1990s also generated wide interest and controversy (Berg 1994; Fischer et al. 1996). Excessive corporate debt does not seem to have been the subject of previous analyses, probably because the level of corporate debt in East Asia is unprecedentedly high. Stone $(1998 ; 2000 a ; 2000 b)$ provides a general assessment of corporate sector dynamics in systemic financial crises and corporate sector restructuring in East Asia. See also Hutchison and Noy (2005).

${ }^{4}$ Krugman (1999) suggests that a cutoff of capital inflows reduces investor/borrower wealth and shifts up the current account balance, which requires an output contraction and depreciation-led import compression. Worse, the depreciation raises external debt payment and furthers reduce wealth, investment, and output, and puts the economy into a low output equilibrium.

${ }^{5}$ The initial debt-equity ratio will be determined by governance, openness, and other factors. Johnson et al. (1999) concluded that corporate governance explains the extent of depreciations and stock market declines in the East Asia crisis better than standard macroeconomic measures. World Bank (1998), Stone (2000a), and Gobat (1998) discuss the determination of debt-equity ratios in East Asia during the run up to the crisis. See also Kim (2004).
} 
that the crisis is rooted more in high levels of corporate debt than in moral hazard-driven domestic lending or bank runs, and that the independent role of banks is less important than the root weaknesses of the corporate sector.

The paper is organized as follows. The basic model is presented in Section II, and applied to the low, medium, and the high debt cases in Section III. The empirical evidence is presented in Section IV, and Section V concludes.

\section{The Basic Model}

A simple general equilibrium small open economy model is developed here to analyze the consequences of different levels of corporate leverage for the adjustment of aggregate output to a sudden cutoff of capital inflows.

\section{A. Firms}

There are a continuum of firms at time $t$, indexed by $j \in\left(0, n_{t}\right)$, $n_{t}>0$. Each firm has a constant returns to scale production function with physical capital and labor input

$$
y_{t}=A k_{t}^{\alpha} l_{t}^{1-\alpha}
$$

where $y_{t}$ denotes value added from current output, $k_{t}$ capital stock, $l_{t}$ labor, and $\alpha(\in(0,1)$ ) the capital share parameter (subscripts denoting that the variable is for an individual firm are for the most part omitted). Each firm has an identical level of capital at the time of the liquidity shock. In the context of this paper, capital stock can be broadly interpreted to include inventory, especially if the high rate of post-crisis inventory decumulation in East Asia reflects fire sales of inventory by leveraged corporations (as opposed to typical business cycle factors as in Ramey and West (1997)). This model introduces capital irreversibility into the literature on post-crisis output adjustment. 6 The transformation of a unit of capital sold by a troubled firm back into a final good, and thereafter into capital or consumption by a new owner, is assumed to be wasteful (putty-clay

\footnotetext{
${ }^{6}$ See Pindyck (1991) and Bernanke (1983) for analysis of the effects of irreversibility on investment.
} 
technology). The wastefulness of capital sales arises from:

- physical/technological traits of an asset, such as embodied technology, factor substitution possibilities, and in the types of products they can produce, limit its alternative uses, and thereby make it less useful to the buyer than to the seller (Williamson 1988); 7

- asset market imperfections, such as market thinness or information asymmetries, that drive a wedge between the replacement cost of an asset and its purchase price (Ramey and Shapiro 2001); and,

- macroeconomic considerations that reduce the asset sale price to below its value in best use. Specifically, shocks that induce an asset sale generally also reduce the cash flow of potential buyers in the same industry and thus lower the price they can pay. (If assets are sold outside the industry, asset market imperfections may further reduce the sales price.) The large economy-wide shocks and interindustry shifts in assets (including large sales to foreign investors) in East Asia suggest these macroeconomic considerations could be substantially reducing asset sale prices in the region. Capital sold under distress or liquidating conditions is assumed to be wasteful.

The wastefulness of capital sales is normally much higher when firms went bankrupt than when they stay afloat. Thus, we distinguish between capital sales by firms that stay afloat and by firms that go bankrupt. Distress capital sales $\left(s_{t}^{d}\right)$, defined as capital sales made by firms that successfully stay afloat in the face of a liquidity shock, are at a discount: 8

$$
s_{t}^{d}=z k_{t}^{d}, \quad z<1
$$

\footnotetext{
${ }^{7}$ Ramey and Shapiro (2001) use the real-life example of a wind tunnel capable of producing winds up to 270 miles per hour that was sold by an aerospace company and rented out to bicycle helmet designers and architects, who required wind speeds much less than 270 miles per hour. This sale can be viewed as wasteful because a key trait of the wind tunnel-high air speeds-had no value for the new users.

${ }^{8}$ Studies of distress capital sales indicate that these discounts are quite large: the sale of the Campeau retail empire was at discounts of 32 percent (Kaplan 1989), and Ramey and Shapiro (2001) concluded that the discount (sales price relative to replacement value) on asset sales in the airline industry is 43-63 percent during a sectoral downturn.
} 
where $k_{t}^{d}$ is the amount of capital stock sold, $z$ is the price of a unit of capital on distress sales, and thus $(1-z)$ is the discount, or the amount of a unit of capital wasted. This relatively simple specification is used rather than an explicit model of a physical capital market for the sake of tractability.

Liquidation capital sales $\left(s_{t}^{l}\right)$, defined as capital sales made by firms that do go bankrupt and must liquidate, are assumed to be even more wasteful:

$$
\boldsymbol{s}_{t}^{l}=\boldsymbol{x} k_{t}^{l}, \quad \boldsymbol{x}<\boldsymbol{z}
$$

where $k_{t}^{i}$ is the amount of capital stock sold by bankrupt firms, $x$ is the price of a unit of capital on liquidation sales.

Because the liquidation price $x$ is less than the distress price $z$, firms always undertake wasteful (distress) capital sales to avoid a bankruptcy-induced wipe out of their value. ${ }^{9}$ Firms issue bonds and equity. The cost of capital is a weighted sum of the cost of bonds, which pay real interest $r_{b t}$, and the net cost of equity $r_{e t}$, which is the sum of dividend yield and capital gains. ${ }^{10}$ The number of equity shares is kept constant at $Q$, so that new investment is financed by retained earnings. The debt-equity ratio $\lambda$ is the crucial starting condition of the analysis. The cross-country difference in the debtequity ratio may reflect the differences in tax incentives, regulations, corporate governance, and other factors across countries.

The liquidity shock takes the form of an interruption of the rollover of foreign debt. Borrowing in terms of domestic currency is $e_{t} b_{t}$, where $b_{t}$ denotes one-period dollar-denominated foreign bonds and $e_{t}$ is the exogenously-given exchange rate. Bonds are assumed to be short term to capture the strong reliance of corporations in East Asia on short-term credit to finance long-term investment. Ordinarily,

\footnotetext{
${ }^{9}$ The assumption of $\boldsymbol{x}<\boldsymbol{z}$ can be justified on the grounds that: the assets of nonviable firms are less deployable than those of other firms; economies with bankrupt firms will be in deep recession and therefore asset prices will be lower; and that firms have distinct classes of physical capital $\left(k_{i}\right)$ which differ in their reversibility, and when the liquidity constraint is binding, the firm sells first its units of capital that involve less waste. A case study of the liquidation of the assets of a machine tool manufacturer reported discounts of 50 to 70 percent (Holland 1990).

${ }^{10}$ That is, $r_{e t}=d_{t}+\left(q_{t}-q_{t-1}\right) / q_{t-1}$ where $q_{t}$ is the price of equities, and $d_{t}$ is the dividend yield $\left(D_{t} / q_{t-1} Q\right.$ where $D_{t}$ is total dividends). Given the debt-capital ratio $\lambda$, the total real cost of capital is $\rho_{t}=r_{b t} \lambda+r_{e t}(1-\lambda)$.
} 
foreign creditors renew the bonds, but when their confidence falters, especially in response to external developments, they may suddenly at the beginning of the period refuse to roll over the debt, which from the standpoint of the firm is a random liquidity shock with probability $\phi$. Since the rate of interest is given at the international level $r_{b t}$, the liquidity shock does not alter the bond interest rate, but it does change the return on equity.

Profits left over from interest and wage payments are used first to raise investment, and then are paid to shareholders as dividends, as long as the liquidity constraint is non-binding. However, if the debt is not rolled over and the liquidity constraint binds, then the firm pays its principal and interest payments, and allocates the rest of profits to investment and dividends. If profits fall short of debt payments and the unconstrained level of investment, then the firm pays no dividends at all.

Firms sell part or all of their capital stock if profits are insufficient to meet their debt payment. The liquidity shock is revealed at the beginning of the period, but principal and interest payments take place after production, so that firms can use their capital for current production, and then sell it in the same period. The portion of capital stock sold within period $t$, a choice variable for the firm, is denoted by $\gamma_{t}$. Thus, the amount of capital sold is $\gamma_{t}(1-\delta) k_{t}$, and the law of motion for capital is

$$
k_{t+1}=\left(1-\gamma_{t}\right)(1-\delta) k_{t}+i_{t}
$$

where $\delta$ is the depreciation rate, and $i_{t}$ denotes gross investment.

Firms are risk-neutral and maximize the present discounted value of their net cash flows. The firm's value and cost of capital are derived from its constraints, following Brock and Turnovsky (1981) and Kim (1998). If the firm does not go bankrupt, its value is:

$$
V_{0}=E_{0} \sum_{t=0}^{\infty} \frac{\left[p_{t} y_{t}+p_{t} z \gamma_{t}(1-\delta) k_{t}-w_{t} l_{t}\right]-p_{t}\left[k_{t+1}-(1-\delta) k_{t}+\gamma_{t}(1-\delta) k_{t}\right]}{\prod_{s=0}^{t}\left(1+\rho_{s}\right)}
$$

where $\rho_{s}$ is the firm's discount rate, $w_{t}$ is the wage rate and $E_{t}$ is the expectation operator given information at time $t$. The firm chooses its optimal capital stock, effective labor, and capital sales to maximize 
its value, taking prices as given.

The firm's operative liquidity constraint depends on whether or not it is hit by a liquidity shock:

No liquidity shock: $p_{t} y_{t}-w_{t} l_{t}+p_{t} z \gamma_{t}(1-\delta) k_{t} \geq r_{b t} e_{t} b_{t}$

(with probability $1-\phi$ )

Liquidity shock: $p_{t} y_{t}-w_{t} l_{t}+p_{t} z \gamma_{t}(1-\delta) k_{t} \geq\left(1+r_{b t}\right) e_{t} b_{t}$

(with probability $\phi$ )

Finally, the model incorporates bankruptcy for nonrepayment of debt. If a firm cannot meet its debt obligation in the current period (i.e. if the liquidity constraint binds) even after eliminating investment and dividends, and selling all of its capital, then it goes bankrupt.11 If the firm goes bankrupt, its value drops to the proceeds from its capital sales:

$$
V_{0}^{x}=x(1-\delta) k_{t}
$$

\section{B. Consumers}

There are a large number of identical consumers in the economy measured as $m<n_{t}$ who maximize the following intertemporal utility function:

$$
E_{0} \sum_{t=0}^{\infty} \beta^{t} c_{t}
$$

where $c_{t}$ is consumption of each resident and $\beta$ is the subjective discount factor. Each consumer has one unit of time for labor and $Q_{t}$ units of equity shares at the beginning of the period, and his budget constraint is:

$$
p_{t} c_{t}+q_{t+1}\left(Q_{t+1}-Q_{t}\right) \leq d_{t} q_{t} Q_{t}+w_{t} l_{t}^{s}
$$

\footnotetext{
${ }^{11}$ The assumption here is that the creditor is willing to let the firm go bankrupt when it cannot meet the current payment and even before it is technically insolvent based on its net present value i.e. the creditor would rather pull out immediately than reschedule the bonds. This assumption accords with the quick withdrawal of creditors in East Asia during late 1997 and 1998 (Roubini et al. 1998), and is in the same spirit as the show me the money constraint in Corsetti et al. (1998).
} 
where $Q_{t+!}$ is the demand for equity, and $l_{t}^{s}$ is the supply of labor. The left hand side is expenditures, i.e., consumption and equity purchases. The right hand side is net income, or the sum of income from equity and labor. Labor is not mobile over one period because it is costly for the agent to move to work for a new firm. Given prices and a fixed supply of equity (i.e., $Q_{t}=Q_{t+1}$ ), each consumer supplies one unit of labor and consumes

$$
c_{t}=\left(w_{t}+d_{t} q_{t} Q_{t}\right) / p_{t}
$$

Consumption decreases in response to an increase in $p_{t}$ and realization of the adverse liquidity shock, which shifts the domestic demand curve to the left. Net export demand of the final good reflects the real exchange rate:

$$
N X_{t}=N X\left(e_{t} / p_{t}\right), N X^{\prime}>0
$$

\section{Aggregate Supply and Demand}

The supply of each surviving firm (denoted by $s_{t}$ ) is the sum of its current production, as well as its distress capital sales, if any,

$$
s_{t}=y_{t}+s_{t}^{d}
$$

Similarly, the supply of each liquidating firm in time $t$ is simply the sum of its output and capital sales $s_{t}^{l} .12$ Capital sales increase the available supply of goods to beyond the level of current production/value added, and thereby shift out the supply curve. Aggregate supply at time $t$ (denoted by $S_{t}$ ) is thus the sum over all firms of aggregate current production and aggregate distress and liquidating capital sales

$$
S_{t}=\sum A k_{t}^{\alpha} l_{t}^{1-\alpha}+\sum z \gamma_{t}(1-\delta) k_{t}+\sum x(1-\delta) k_{t}
$$

Finally, aggregate demand is

$$
D_{t}=m c_{t}+\sum i_{t}+N X_{t}
$$

\footnotetext{
${ }^{12}$ Appendix examines the case where bankruptcy and capital sales take place before production.
} 
Note that, in this model, consumption and investment can come not only from currently produced output, but also from capital sales.

\section{The Impact of a Liquidity Shock on the Real Economy}

The impact of an adverse liquidity shock on an economy critically depends on the level of corporate leverage. In this section, we distinguish between low-debt, medium-debt and high debt regimes, and analyze the impact of a liquidity shock on output, wages, and prices for a low-debt economy as a benchmark case. We then compare the benchmark case with the cases of medium and high-debt economies and a two-period bond case. These comparisons show a direct relation between corporate leverage and the magnitude of a liquidity shock-induced output contraction.

\section{A. Low-Debt Regime: Neither Capital Sales nor Bankruptcies}

In this benchmark case, debt is so small that firms need not sell capital even in the event of a liquidity shock.

Low-Debt Regime: For all firms $j \in\left(0, n_{t}\right)$ and for all $t$ :

$$
p_{t} y_{t}-w_{t} l_{t}>\left(1+r_{b t}\right) e_{t} b_{t}
$$

Even if the debt is not rolled over (requiring the firm to come up with $\left(1+r_{b t}\right) e_{t} b_{t}$ rather than $\left.r_{b t} e_{t} b_{t}\right)$ the liquidity constraint is not binding, implying that firms never have to sell their capital.

The optimal capital stock and investment are determined in the low-debt case as if there were no liquidity shock. The optimizing firm equates its net marginal return from investment to the net marginal cost

$$
p_{t}\left(\left(d y_{t} / d k_{t}\right)+z \gamma_{t}(1-\delta)\right)=p_{t-1}\left(\rho_{t}-\delta\right)
$$

implying that the capital stock in $t$, and investment in $t-1$, are decreasing in the relative price $p_{t-1} / p_{t}$ and also reflect the values of $z$ and $\gamma$. This relationship and the other first order condition that the real wage rate equals the marginal productivity of labor generate the optimal capital-labor ratio, which, given the constant labor supply, yields the optimal capital stock.

Although low-debt firms have the option of selling their capital to 
other firms and households (domestic or foreign) they will not do so because capital sales reduce their value, as can be seen from the derivative of $V_{0}$ with respect to $\gamma_{t}$ :

$$
d V_{0} / d \gamma_{t}=(z-1) p_{t}(1-\delta) k_{t}<0
$$

Therefore, the optimal level of capital sales is $\gamma_{t}=0$ for all $j \in\left(0, n_{t}\right)$. If the profit remaining after debt payment is large enough to finance the level of investment needed for the optimal level of capital stock, then the liquidity constraint can be seen as nonbinding. Alternatively, the liquidity constraint binds if the amount available for investment falls short of that needed to yield the optimal capital stock. In both cases, however, firms make positive investment to at least compensate for the depreciation of capital.

Aggregate supply is

$$
S_{t}=n_{t}\left[\left(p_{t} / w_{t}\right)(1-\alpha)\right]^{(1-\alpha) / \alpha} k_{t}
$$

which is a standard upward-sloping supply curve. Aggregate demand is

$$
D_{t}=m c_{t}+n_{t} i_{t}+N X_{t}=m\left(w_{t}+d_{t} q_{t} Q_{t}\right) / p_{t}+n_{t} i_{t}+N X_{t}
$$

which is a downward-sloping curve.

\section{B. Medium-Debt Regime: Capital Sales but No Bankruptcies}

Corporate leverage is high enough to adversely impact the real sector in the medium-debt economy. Here, the elimination of investment and wasteful capital sales by medium-debt firms struggling to stay afloat in the face of a liquidity shock reduce the aggregate capital stock, contract output, and lower prices

Medium-Debt Regime: For low debt firms $j \in\left(0,\left(1-\theta_{1}\right) n_{t}\right)$ :

$$
p_{t} y_{t}-w_{t} l_{t}>\left(1+r_{b t}\right) e_{t} b_{t}
$$

For medium-debt firms $j \in\left(\left(1-\theta_{1}\right) n_{t}, n_{t}\right)$ :

$$
p_{t} y_{t}-w_{t} l_{t} \leq\left(1+r_{b t}\right) e_{t} b_{t}<p_{t} y_{t}+p_{t} z(1-\delta) k_{t}-w_{t} l_{t}
$$


The profits of medium-debt firms are insufficient to pay off their debt if it is not rolled over, but they can avoid bankruptcy by eliminating investment and selling their capital.

After the adverse liquidity shock, medium-debt firms must choose between: (i) going bankrupt and selling their capital at the liquidation price $(x<1)$, or (ii) staying afloat by repaying their debt through sales of their capital at the distress price $(z<1)$. Since $z>x$, they choose to stay in business. They produce current output, then sell $\gamma_{t} z(1-\delta) k_{t}$ of their capital to low-debt firms and households (both domestic and foreign), but only up until the liquidity constraint is met. Capital sales are

$$
\gamma_{t}=\frac{\left(1+r_{b t}\right) e_{t} b_{t}-p_{t} y_{t}+w_{t} l_{t}}{p_{t} Z(1-\delta) k_{t}}>0
$$

which are positive, and are increasing in $r_{b t}$ and $b_{t}$ and decreasing in $z$ and $y_{t}$.

Since the only way these firms can finance new investment is by selling capital at a loss, they invest nothing. Thus, investment does not follow from an interior solution that strikes a balance between marginal gain and cost, as in the low-debt case; rather, investment is determined here in a corner solution pulled down by the liquidity constraint.

Output in time $t$ is unaffected by the shock since capital used for production in $t$ is determined in the previous period (Eq. (4)). Thus, the output of both types of firms in the medium-debt case is the same as in the benchmark low-debt case.

However, output contracts in the period after the liquidity shock. The capital stock for medium-debt firms, who do not invest because they are liquidity-constrained, declines to $k_{t+1}=\left(1-\gamma_{t}\right)(1-\delta) k_{t}$. Low-debt firms may raise their investment compared to the benchmark low debt case, due to intertemporal substitution following the increase in $p_{t+1}$ over $p_{t}$. However, it will not be large enough to offset the reduction in capital of medium-debt firms because of diminishing marginal returns. The resulting reduction in the level of aggregate capital, given a constant labor supply, will lead to a contraction in the valued added in $t+1$. The magnitude of the output contraction reflects the extent of the capital reduction $\gamma$, which, in turn, reflects the value of $z$. 
Real wages are also reduced with a lag. Real wages are not impacted right away by the liquidity shock because labor supply per firm is determined at $l_{t}=m / n_{t}$, which is unaltered by the liquidity shock because there are no bankruptcies. However, the decline in aggregate capital stock at time $t+1$, reduces the marginal product of labor, and therefore the real wage drops.

Prices in a medium-debt economy are reduced in period $t$ by an adverse liquidity shock. The supply curve of the individual medium-debt firm is shifted to the right by distress capital sales, implying a proportional (by $\theta_{1} n$ ) shift of their supply, and a rightward shift of the aggregate supply curve by $\theta_{1} n \gamma_{t} z(1-\delta) k_{t}$. Meanwhile, the aggregate demand curve shifts to the left as domestic demand declines not only because investment of medium-debt firms falls to zero, but also due to lower consumption resulting from the elimination of their dividends. The rightward supply curve shift and leftward demand curve shift generate a decline in aggregate prices. The increase in aggregate supply due to capital sales will be met by an increase in net foreign exports induced by a real exchange rate depreciation from the fall in domestic prices. In addition, aggregate supply in $t+1$ will no longer include capital sales, and hence the supply curve is likely to shift back to the left, implying a subsequent reflation.

Finally, following the phase of adjustment to the liquidity shock, output in this model will move back to its pre-crisis level. Indeed, if foreign capital flows resume in the next period, then investment of the medium debt firms will quickly push the capital stock back to its steady state, which induces inflation in the next period, and rapidly increases output.

\section{High-Debt Regime: Capital Sales and Bankruptcies}

In the high-debt economy, some firms go bankrupt, as happened in East Asia during the 1997-98 financial crisis. In this high-debt regime, there are low-debt firms, medium-debt firms who stay afloat by reducing investment and selling capital, and high-debt firms that go bankrupt and must liquidate their capital.

High-Debt Regime: For low debt firms $j \in\left(0,\left(1-\theta_{1}-\theta_{2}\right) n_{t}\right)$ :

$$
p_{t} y_{t}-w_{t} l_{t}>\left(1+r_{b t}\right) e_{t} b_{t} \text {. }
$$




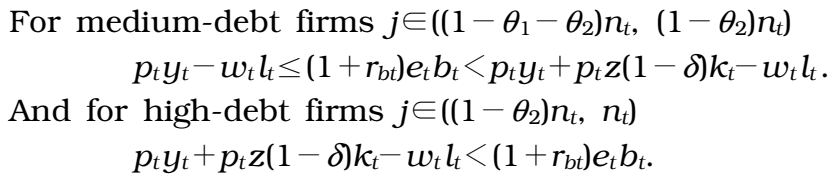

High-debt firms go bankrupt if their debt is not rolled over, even if they eliminate investment and sell all of their capital. Immediately after the liquidity shock, they produce, undertake liquidation sales of capital, pay wages $w_{t} l_{t}$, and distribute the remaining revenue to their creditors.

Again, output contracts in time $t+1$, but by more than in the medium-debt economy. The reason is that the decline in aggregate capital stock is larger in the high-debt regime due to the greater wastefulness of liquidation capital sales compared to distress sales $(x<z)$. Real wages are not altered during the period of the liquidity shock, but they fall in the next period, again due to the reduction in aggregate capital stock, and by more than in the medium-debt economy.

Finally prices also fall in time $t$ after a liquidity shock. The aggregate supply curve is

$$
S_{t}=n_{t}\left[\left(p_{t} / w_{t}\right)(1-\alpha)\right]^{(1-\alpha) / \alpha} k_{t}+\theta_{1} n_{t} \gamma_{t}(1-\delta) k_{t}+\theta_{2} n_{t} x(1-\delta) k_{t}
$$

The rightward shift of the supply curve exceeds that of the medium-debt regime due to greater capital sales. Similarly, the aggregate demand curve shifts to the left by more than in the medium-debt economy as domestic demand declines because of the fall in investment of medium-debt and high-debt firms to zero, and lower consumption resulting from the elimination of dividends of medium-debt and high debt firms.

The comparison among low-debt, medium-debt and high-debt regimes suggests that the higher debt an economy has, the greater the output contraction following a liquidity shock. Within mediumdebt or high-debt regime, an increase in corporate leverage tends to raise the magnitude of output contraction due to an adverse liquidity shock. Furthermore, if an increase in corporate leverage induces a regime shift from low-debt to medium-debt or from medium-debt to high-debt regime, the leverage effect is further amplified. 
D. Medium-Debt Regime with Multi-Period Financing: Deflationary Channel

Multi-period corporate financing can further amplify the output contraction through the impact of expected future deflation. This extra link between corporate leverage and output, which is in addition to the previously demonstrated contractionary channels of lower investment from a tighter budget constraint and wasteful capital sales, is discussed here using the medium-debt economy case. Assume now that half of medium-debt firms are financed by one-period bonds, while the other half tap two-period bonds. Foreign creditors at the beginning of time $t$ refuse to roll over the debt that matures at the end of $t+1 .{ }^{13}$

Here, output in period $t+1$ will be given further downward impetus by extra deflation arising from the liquidity shock. All firms in $t$ will expect medium-debt or high-debt firms with two-period bonds to make distress capital sales at $t+1$ to meet their future financing gap, and, they know that these sales will exert downward pressure on $p_{t+1}$ (based on the same reasoning that sales in $t$ reduce $p_{t}$ ). In response, all firms will want to curtail their future production $y_{t+1}$. The only way they can reduce their future output (given a constant labor supply) is by shrinking $k_{t+1}$, which means cutting back on investment today. As before, $y_{t}$ is fixed by the predetermined level of $k_{t}$ and the fixed labor supply. However, the lower level of investment will contract the capital stock, as before, but this contraction will be even larger due to the expectation of price deflation next period. Thus, $y_{t+1}$ will be smaller when bonds are issued for different maturities compared to the one period case.

\section{Discussion: East Asian Experience}

In this section, experience of output adjustment in the highly leveraged East Asian countries during the 1997-98 financial crisis is examined with a view to illustrating the validity of the assumptions and predictions of the model.

The trigger for the chain of events set out in the model is an exogenous cutoff of external credit. As shown in the middle panel of

\footnotetext{
${ }^{13}$ Alternatively, period $t$ can be divided into sub-periods $t_{1}$ and $t_{2}$, and bonds can be issued at maturities of $t_{1}$ and $t_{1}+t_{2}$.
} 


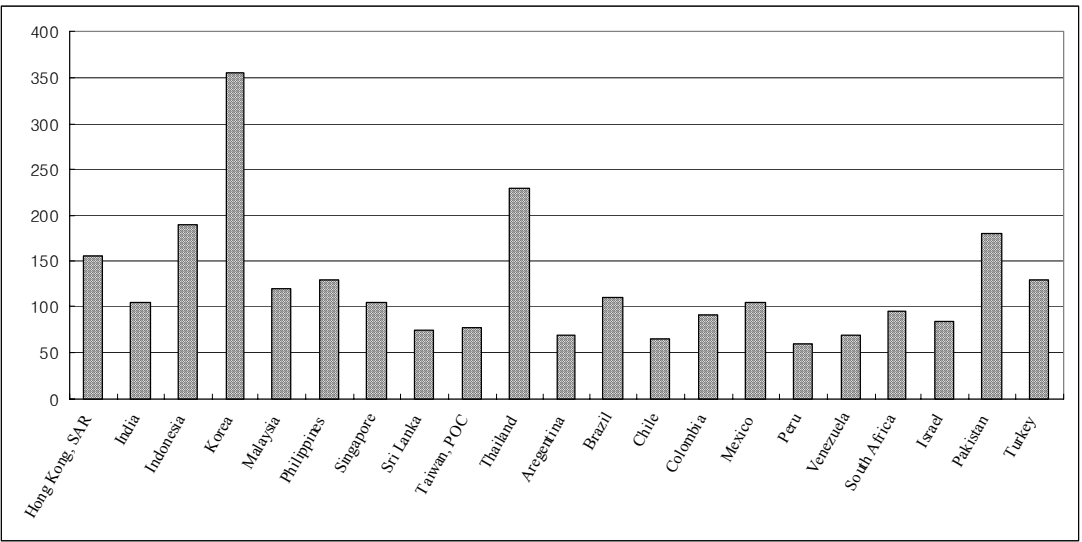

FIGURE 2

Selected Countries: Corporate Leverage in 1996

Figure 1, the plunges in gross private capital flows (which is the measure used in the World Economic Outlook of the IMF) for East Asia during 1998 were remarkably abrupt, large, and pervasive and even relatively healthy countries like Singapore and Taiwan were hit hard. Thus, a cutoff of credit for both low and high debt countries appears to be a reasonable assumption. A high level of corporate debt prior to the cutoff of external credit is another crucial assumption of the model. The pre-crisis level of corporate leveraging, as measured by the debt-equity ratio in 1996, is indeed quite high by international standards generally in East Asia, but especially for Indonesia, Korea and Thailand (Figure 2). ${ }^{14}$ Moreover, corporate debt became much higher after the crisis than before the crisis owing to the impact of large exchange rate depreciations on the local value of external debt and the buildup of arrears on domestic debt.

The model predicts that the cutoff of credit will trigger a large number of bankruptcies in countries with highly-leveraged corporate sectors. In the absence of comparable cross-country bankruptcy

\footnotetext{
${ }^{14}$ The data set developed by Claessens et al. (1998) is for nonfinancial companies and comes from annual reports of those companies listed on the major stock exchanges in the region and from the World scope and Extel databases. The number of companies per country ranges from 170 for the Philippines to 636 for Malaysia.
} 

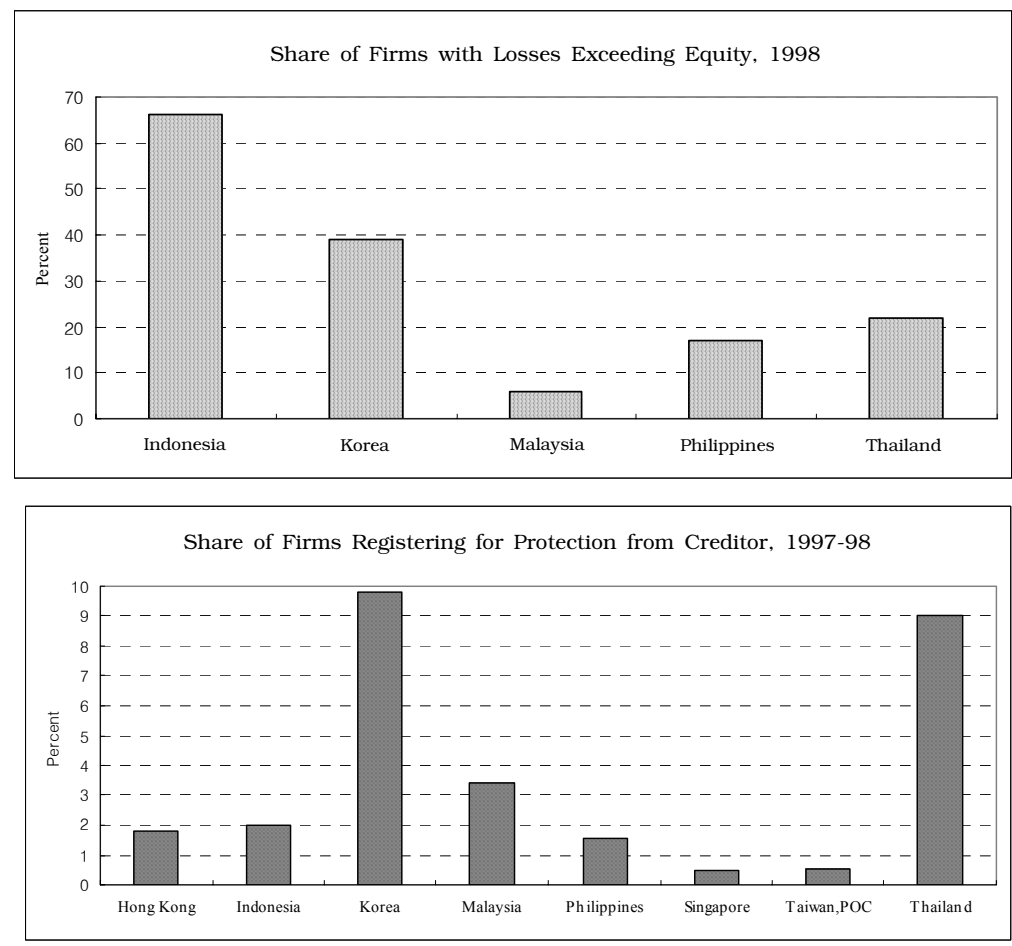

Source: World Bank (1998).

Figure 3

BANKRUPTCY INDICATORS IN EAST ASIA DURING 1997-98

data, two proxies are used here. First, the World Bank (1998) estimated the share of "nonviable" firms (facing estimated losses exceeding equity) as of early 1998. These figures, which are available for only five East Asian countries, suggest a rough correspondence between corporate leverage and nonviability (Figure 3, top panel). Second, a comprehensive cross-country microeconomic data set of nonfinancial firms shows that the share of corporations that filed for legal creditor protection during 1997-98 was much larger in the highly leveraged countries (Figure 3, bottom panel), with the exception of Indonesia, where the incomplete implementation of bankruptcy and judicial reform during 1997 and 1998 delayed bankruptcy procedures for nonviable firms. 15 Analysis of this data

${ }^{15}$ Bankruptcy reform developments in Indonesia are documented in the 
TABLE 1

INFLATION AND DEPRECIATION IN EAST ASIA, 1990-99

\begin{tabular}{c|c|r|r|r|r|r|r|c}
\hline \hline & Hong Kong & Indonesia & Korea & Malaysia & Philippines & Singapore & Taiwan & Thailand \\
\hline Annualized inflation 1) & & & & & & & & \\
June 1997 - August 1999 & 0.5 & 36.8 & 4.0 & 4.2 & 7.4 & -0.5 & 1.8 & 4.5 \\
January 1990 - June 1997 & 8.4 & 8.1 & 6.0 & 3.8 & 9.5 & 2.3 & 3.4 & 4.9 \\
\hline Annualized deflation 2) & & & & & & & & \\
June 1997 - August 1999 & -1.8 & 59.8 & 13.3 & 16.0 & 15.2 & 3.6 & -0.1 & 15.7 \\
January 1990 - June 1997 & -1.5 & 2.0 & 4.1 & -2.2 & -0.7 & -3.5 & 1.2 & -1.4 \\
\hline
\end{tabular}

Source: IFS

Notes: 1) CPI, seasonally adjusted.

2) Nominal effective exchange rate.

set concluded that leverage was an important determinant of filing for legal credit on protection (Claessens et al. 1999, Table 7).

Deflation in output prices is predicted by the model for countries with high corporate debt. At first glance, inflationary pressures in most East Asian countries during mid-1997 to August 1999 are not out of line with the pattern for the 1990s, except for Indonesia (top 2 rows of Table 1). However, these rates of inflation are quite low for the highly leveraged and open countries when the large rates of depreciation are taken into account (bottom 2 rows of Table 1). Thus, deflationary pressures appear to be quite strong for the highly leveraged countries in East Asia.

Output of highly leveraged countries will be hit by a contraction in investment by corporations facing a credit cutoff, according to the model. During 1998, countries with higher levels of corporate debt (Indonesia, Korea, and Thailand) did indeed experience very sharp declines in investment (Table 2). These declines were so large that the contribution of investment to real GDP growth for the highly leveraged East Asian countries were equal to or even in excess of the overall contraction in GDP.16 These contractions were larger than

Government of Indonesia's Letters of Intent and Memorandum of Economic and Financial Policies which are available on the IMF website (http:// www.imf.org/external/np/loi/1999/051499.htm).

${ }^{16}$ Corporate leverage has the largest correlation with growth in 1998 across 21 large emerging economies that experienced dropoffs in capital inflows during 1998 compared to the other candidate variables for the crisis listed in section I. In addition, regressions of growth in 1998 on corporate leverage and other candidate explanatory variables that predate the output contraction 
TABLE 2

GDP GROWTH AND CONTRIBUTION OF INVESTMENT AND INVENTORY DURING CRISIS

(Annual growth, in percent)

\begin{tabular}{|c|c|c|c|c|c|}
\hline \multicolumn{3}{|c|}{ East Asia Crisis, 1998-99 } & \multicolumn{3}{|c|}{ Tequila Crisis, $1995-96$} \\
\hline & 1998 & 1999 & & 1995 & 1996 \\
\hline $\begin{array}{l}\text { Hong Kong } \\
\text { Gross domestic product } \\
\text { Con. of gross fixed cap. form. } \\
\text { Con. of inventory change }\end{array}$ & $\begin{array}{r}5.1 \\
-2.3 \\
2.5\end{array}$ & $\begin{array}{r}1.1 \\
-1.4 \\
0.0\end{array}$ & $\begin{array}{l}\text { Argentina 1) } \\
\text { Gross domestic product } \\
\text { Con. of gross fixed cap. form. }\end{array}$ & $\begin{array}{l}-2.8 \\
-2.7\end{array}$ & $\begin{array}{l}5.5 \\
1.6\end{array}$ \\
\hline $\begin{array}{l}\text { Indonesia } \\
\text { Gross domestic product } \\
\text { Con. of gross fixed cap. form. } \\
\text { Con. of inventory change }\end{array}$ & $\begin{array}{r}-13.7 \\
-11.6 \\
-5.4\end{array}$ & $\begin{array}{r}-0.8 \\
-3.2 \\
0.0\end{array}$ & $\begin{array}{l}\text { Brazil 1) } \\
\text { Gross domestic product } \\
\text { Con. of gross fixed cap. form. }\end{array}$ & $\begin{array}{l}4.2 \\
1.1\end{array}$ & $\begin{array}{l}2.8 \\
0.3\end{array}$ \\
\hline $\begin{array}{l}\text { Korea } \\
\text { Gross domestic product } \\
\text { Con. of gross fixed cap. form. } \\
\text { Con. of inventory change }\end{array}$ & $\begin{array}{l}-5.8 \\
-7.3 \\
-5.6\end{array}$ & $\begin{array}{l}6.5 \\
0.1 \\
5.3\end{array}$ & $\begin{array}{l}\text { Mexico } \\
\text { Gross domestic product } \\
\text { Con. of gross fixed cap. form. } \\
\text { Con. of inventory change }\end{array}$ & $\begin{array}{l}-6.2 \\
-5.6 \\
-2.1\end{array}$ & $\begin{array}{l}5.2 \\
2.4 \\
1.6\end{array}$ \\
\hline $\begin{array}{l}\text { Malaysia } \\
\text { Gross domestic product } \\
\text { Con. of gross fixed cap. form. } \\
\text { Con. of inventory change }\end{array}$ & $\begin{array}{r}-6.7 \\
-21.2 \\
0.4 \\
\end{array}$ & $\begin{array}{l}2.4 \\
2.5 \\
0.3\end{array}$ & & & \\
\hline $\begin{array}{l}\text { Philippines } \\
\text { Gross domestic product } \\
\text { Con. of gross fixed cap. form. } \\
\text { Con. of inventory change }\end{array}$ & $\begin{array}{r}-0.5 \\
-3.0 \\
-1.4 \\
\end{array}$ & $\begin{array}{r}2.3 \\
-3.5 \\
1.4 \\
\end{array}$ & & & \\
\hline $\begin{array}{l}\text { Singapore } \\
\text { Gross domestic product } \\
\text { Con. of gross fixed cap. form. } \\
\text { Con. of inventory change }\end{array}$ & $\begin{array}{r}1.5 \\
-2.0 \\
-3.3 \\
\end{array}$ & $\begin{array}{l}3.1 \\
1.1 \\
3.6 \\
\end{array}$ & & & \\
\hline $\begin{array}{l}\text { Taiwan POC } \\
\text { Gross domestic product } \\
\text { Con. of gross fixed cap. form. } \\
\text { Con. of inventory change }\end{array}$ & $\begin{array}{l}4.9 \\
1.3 \\
0.4 \\
\end{array}$ & $\begin{array}{l}4.4 \\
1.0 \\
0.3 \\
\end{array}$ & & & \\
\hline $\begin{array}{l}\text { Thailand } \\
\text { Gross domestic product } \\
\text { Con. of gross fixed cap. form. } \\
\text { Con. of inventory change }\end{array}$ & $\begin{array}{r}-9.4 \\
-13.2 \\
-1.1\end{array}$ & $\begin{array}{l}2.6 \\
0.7 \\
0.8\end{array}$ & & & \\
\hline
\end{tabular}

Source: World Economic Outlook Database, IMF (1999).

Note: Changes in inventories are not reported separately.

those experienced by Mexico, Argentina, and Brazil during the "Tequila Crisis" of 1995 (Table 2).17 Moreover, even for 1999, invest-

suggest that capital inflows have little explanatory power, whereas the corporate leverage parameter estimates consistently have the highest $t$-statistics and their omission greatly worsens the fit across different specifications (results are available from the authors).

${ }^{17}$ See also Perry and Lederman (1999) and Lane et al. (1999). 
ment was not expected to contribute to growth, suggesting that at least in the short-term investment will not lead the recovery.

Another key prediction of the model is that output will be reduced by capital sales at a discount by firms struggling to stay afloat or creditors to bankrupt firms after a cutoff of credit. In practice, capital sales can be divided into three categories: (i) direct sales undertaken by the debtor firm directly to another firm; (ii) indirect sales by banks who sell goods used as collateral for loans after having taken the loans after nonrepayment; and, (iii) indirect sales by government asset management corporations (AMCs) who sell goods that are collateral for nonperforming loans (NPLs) that they buy from bad banks.

There is evidence that capital sales even within two years after the onset of the crisis were large enough to have macroeconomic consequences in East Asia, particularly in Korea.18 For example, during the first half of 1999, the top 5 chaebol sold $\$ 6$ billion in assets (Reuters, August 24, 1999). The amount of collateral that creditors of Daewoo planned to liquidate was worth the equivalent of 3 percent of 1998 GDP. The share of total NPLs as of March 1999 for which debt workout agreements had been reached was 23 percent for Korea, 17 percent for Malaysia, and 11 percent for Thailand (International Monetary Fund 1999).

The available data also suggest that discounts on asset sales during the crisis are large. The average discount on nonperforming loans purchased by March 1999 by the Malaysian government AMC was 40 percent, while NPLs bought by the AMC of Korea averaged 55 percent for secured loans and 97 percent for unsecured loans. While these NPL discounts can be viewed as a lower bound on the ultimate sale of the underlying collateral, they nevertheless should be significant. Large discounts are not surprising in light of the evidence on capital sales which concluded that the price of assets sold in distress conditions relative to their replacement value are low.

\section{Conclusion}

This paper has provided a framework showing how a highly

${ }^{18}$ See Mako (2002) and International Monetary Fund (1999) for reviews of progress toward corporate restructuring and capital sales in East Asia. 
leveraged corporate sector can magnify the impact of a liquidity shock on the real economy, as seems to be happening in East Asia during the financial crisis. To avoid bankruptcy in the face of a credit cutoff, excessively leveraged firms reduce investment and sell their capital at a discount. Low investment and wasteful capital sales shrink the capital stock, trigger deflationary pressures, and thereby reduce output and prices. The available evidence suggests that the East Asian countries with the highest level of corporate leverage are experiencing sharp investment declines, capital sales, and the largest output contractions.

The analysis of this paper may have several broader implications. First, at the risk of stating the obvious, policy makers should take care to ensure that corporations do not build up levels of debt that could leave aggregate output excessively vulnerable to a cutoff of external financing. Second, excessive corporate leverage may help explain the sharp investment declines that corresponded to the largest of the output contractions in East Asia during 1998. Third, capital sales prompted by corporate restructuring have occurred, especially in Korea. While the impact on output of these sales might be smaller than that of investment, their novelty and potential to help shape the contour of the macroeconomic development of crisis-hit countries with highly leveraged corporate sector warrants close monitoring.

(Received 3 August 2007; Revised 5 December 2007)

\section{Appendix: Impact of Liquidity Shocks if Bankruptcy and Capital Sales Occur before Production}

This appendix shows that liquidity shocks reduce output in the current period if it is assumed that bankruptcy and capital sales occur before production. When bankruptcy occurs before the high-debt firms produce, they sell capital at liquidation value, so that their total output at time $t$ is zero, and the contractionary effect of a liquidity shock on output is felt without a lag. After the bankruptcy of high-debt firms, a fraction $\theta_{2}$ of workers shift costly to the surviving firms. The labor shift increases the output of low-debt and medium-debt firms at time $t$, since the surviving firm's capital stock at time of liquidity shock is unchanged, but their labor utilization 
increases by $\left(1+(1-v) \theta_{2}\right)$, where $v$ is the cost of labor adjustment. For simplicity, suppose that capital sales liquidation price $x$ is close to zero. The current output of surviving firms then does not increase by as much as the increase in their labor supply because of diminishing returns to labor given the capital stock. Therefore, the output at the time of liquidity shock declines. Of course, as a result of capital sales of medium-debt firms and bankruptcy of high-debt firms, output in the next period will also decline, and the high-debt output decline will exceed the medium-debt output decline. The key result of the model that the higher debt an economy has, the greater the output contraction following a liquidity shock, continues to hold.

Further, the price fall at the time of liquidity shock may not be as large as in the medium-debt case, because the total supply of the high-debt firms will be reduced to zero. With sufficiently low $x$, the increase in capital sales from bankruptcy is less than the reduction in the current output. In addition, the capital sales of the medium-debt firms in the high-debt regime will also be smaller than in the medium-debt regime because the decline in real wages allows the surviving firms to generate more revenues from production $\left(p_{t} y_{t}-w_{t} l_{t}\right)$, and the number of firms decreases from $n_{t}$ to $n_{t}\left(1-\theta_{2}\right)$. Hence, the aggregate supply curve in the high-debt regime is to the left of that for the medium-debt regime, and the price fall in the high-debt regime will be lower than in the medium-debt regime.

\section{References}

Berg, Andrew. "Supply and Demand Factors in the Output Decline in East and Central Europe." Empirica-Austrian Economic Papers 21 (No. 1 1994): 3-36.

Bernanke, Ben. "Irreversibility, Uncertainty, and Cyclical Investment." Quarterly Journal of Economics 98 (No. 1 1983): 85-106.

Brock, William, and Turnovsky, Stephen. "The Analysis of Macroeconomics Policies in Perfect Foresight Equilibrium.” International Economic Review 22 (No. 1 1981): 179-209.

Calvo, Guillermo, and Mendoza, Enrique. Rational Herd Behavior and the Globalization of Securities Markets. Mimeograph, 1998.

Claessens, Stijn, Djankov, Simeon, and Lang, Larry. Corporate Financing and Risks in the Decade before East Asian 
Financial Crisis. World Bank Policy Research Working Paper No. 2017, 1998.

Claessens, Stijn, Djankov, Simeon, and Klapper, Leora. Resolution of Corporate Distress: Evidence from East Asia's Financial Crisis. World Bank Policy Research Working Paper No. 2133, 1999.

Coe, David, and Kim, Se-Jik (eds.) Korean Crisis and Recovery. Washington D.C. and Seoul: IMF and KIEP, 2002.

Corsetti, Giancarlo, Pesenti, Paolo, and Roubini, Nouriel. Paper Tigers? A Model of the Asia Crisis. NBER Working Paper No. 6783, 1998.

Dooley, Michael. A Model of Crises in Emerging Markets. NBER Working Paper No. 6300, 1997.

Fischer, Stanley, Sahay, Ratna, and Vegh, Carlos A. "Stabilization and Growth in Transition Economies: The Early Experience." Journal of Economic Perspectives 10 (No. 2 1996): 45-66.

Glick, Reuven, and Rose, Andrew. Contagion and Trade: Why Are Currency Crisis Regional? NBER Working Paper No. 6806, 1998.

Gobat, Jeanne. Corporate Restructuring and Corporate Governance. Mimeograph, International Monetary Fund, 1998.

Goldstein, Morris. The Asian Financial Crisis: Causes, Cures, and Systemic Implications. Institute for International Economics, 1998.

Holland, M. When the Machine Stopped. Harvard Business School Press, 1990.

Hutchison, Michael M., and Noy, I. "How Bad Are Twins? Output Costs of Currency and Banking Crises." Journal of Money, Credit and Banking 37 (No. 4 2005): 725-52.

International Monetary Fund. World Economic Outlook. 1999.

Johnson, Simon, Boone, Peter, Breach, Alasdair, and Friedman, Eric. Corporate Governance in the Asian Financial Crisis, 1997-98. Mimeograph, 1999.

Kaplan, Steven N. "Campeau's Acquisition of Federated: Value Destroyed or Value Added?” Journal of Financial Economics 25 (No. 2 1989): 191-212.

Kim, Se-Jik. "Growth Effects of Taxes in an Endogenous Growth Model: To what Extent Do Taxes Affect Economic Growth?" Journal of Economic Dynamics and Control 23 (No. 1 1998): 125-58. 
"Bailout and Conglomeration." Journal of Financial Economics 71 (No. 2 2004): 315-47.

Kochhar, Kalpana, Loungani, Prakash, and Stone, Mark R. The East Asian Crisis: Macroeconomic Developments and Policy Lessons. IMF Working Paper, WP/98/128. International Monetary Fund, 1998.

Krugman, Paul. What Happened to Asia? http://Web.mit.edu/ krugman/www/DISINTER.html, 1998.

- Balance Sheets, Financial Crises, and the Transfer Problem. http://Web.mit.edu/krugman/www/DISINTER.html, 1999.

Lane, Timothy, Ghosh, Atish R., Hamann, Javier, Phillips, Steven, Schulze-Ghattas, Marianne, and Tsikata, Tsidi. IMFSupported Programs in Indonesia, Korea, and Thailand: A Preliminary Assessment. 1999.

Mako, William. "Corporate Restructuring and Reform: Lesson from Korea." In D. Coe and S. Kim (eds.), Korean Crisis and Recovery. 2002.

Masson, Paul. Contagion: Monsoonal Effects, Spillovers, and Jumps between Multiple Equilibria. IMF Working Paper WP/98/142, 1998.

Perry, Guillermo, and Lederman, Daniel. Adjustments after Speculative Attacks in Latin America and Asia: A Tale of Two Regions. World Bank, 1999.

Pindyck, Robert. "Irreversibility, Uncertainty and Investment." Journal of Economic Literature 29 (No. 3 1991): 1110-48.

Ramey, Valerie, and Shapiro, Matthew. "Displaced Capital: A Study of Aerospace Plant Closings.” Journal of Political Economy 109 (No. 5 2001): 958-92.

Ramey, Valerie, and West, Kenneth. Inventories. NBER Working Paper No. 6315, 1997.

Roubini, Nouriel, Corsetti, Giancarlo, and Pesenti, Paolo. What Caused the Asian Currency and Financial Crisis? http:// www.stern.nyu.edu/ nroubini/asia/AsiaHomepage, 1998.

Sachs, Jeffrey, and Radelet, Steve. The Onset of the East Asian Financial Crisis. Mimeograph, Harvard Institute for International Development, 1998.

Stone, Mark, R. Corporate Debt Restructuring in East Asia: Some Lessons from International Experience. Papers on Policy Analysis and Assessment No. 98/13, 1998. 
The Corporate Sector Dynamics of Systemic Financial Crises. IMF Working Paper No. 00/114, 2000a.

Large Scale Corporate Sector Restructuring. IMF Policy Discussion Paper No. 00/7, 2000 b.

Williamson, Oliver E. "Corporate Finance and Corporate Governance." Journal of Finance 43 (No. 3 1988): 567-91.

World Bank. East Asia: The Road to Recovery. 1998. 